\title{
Memantine-induced myoclonus
}

\section{白}

The NMDA receptor antagonist, memantine, is used for symptomatic treatment of Alzheimer disease (AD). ${ }^{1} \mathrm{~A}$ 76-year-old man with mixed $\mathrm{AD}$ and vascular dementia, hypertension, and chronic kidney disease developed head and upper extremity myoclonus (video on the Neurology ${ }^{\circledR}$ Web site at Neurology.org). Memantine was prescribed $(5 \mathrm{mg} / \mathrm{d}) 6$ days before onset. Myoclonus disappeared after memantine withdrawal (video). Amantadine, which also has NMDA receptor antagonistic activity, can cause myoclonus. ${ }^{2}$ Memantine is primarily excreted unchanged via the kidney; its elimination half-life is increased with renal impairment, ${ }^{1}$ which may have induced myoclonus in this case. Blockade of NMDA receptors may play an important role in the pathogenesis of myoclonus.

Naoyuki Kitagawa, MD, PhD, Akihiko Takeuchi, MD, PhD

From the Takeuchi Clinic, Tokyo, Japan.

Author contributions: Dr. Kitagawa: drafting/revising the manuscript, study concept or design, analysis or interpretation of data, accepts responsibility for conduct of research and final approval. Dr. Takeuchi: drafting/revising the manuscript, analysis or interpretation of data, accepts responsibility for conduct of research and final approval, acquisition of data. Study funding: No targeted funding reported.

Disclosure: The authors report no disclosures relevant to the manuscript. Go to Neurology.org for full disclosures.

Correspondence to Dr. Kitagawa: knaoyuki.neurology@gmail.com

1. Effect of renal impairment on the pharmacokinetics of memantine. J Pharmacol Sci 2012;119:324-329.

2. Yarnall AJ, Burn DJ. Amantadine-induced myoclonus in a patient with progressive supranuclear palsy. Age Ageing 2012; 41:695-696. 


\title{
Neurology
}

\author{
Memantine-induced myoclonus \\ Naoyuki Kitagawa and Akihiko Takeuchi \\ Neurology 2014;83;1387 \\ DOI 10.1212/WNL.0000000000000863
}

\section{This information is current as of October 6, 2014}

\section{Updated Information \& Services}

\section{Supplementary Material}

\section{References}

Subspecialty Collections

Permissions \& Licensing

\section{Reprints}

including high resolution figures, can be found at: http://n.neurology.org/content/83/15/1387.full

Supplementary material can be found at: http://n.neurology.org/content/suppl/2014/10/04/WNL.0000000000000 863.DC1

This article cites 2 articles, 0 of which you can access for free at: http://n.neurology.org/content/83/15/1387.full\#ref-list-1

This article, along with others on similar topics, appears in the following collection(s):

All Cognitive Disorders/Dementia

http://n.neurology.org/cgi/collection/all_cognitive_disorders_dementia Myoclonus

http://n.neurology.org/cgi/collection/myoclonus

Myoclonus; see Movement Disorders/myoclonus

http://n.neurology.org/cgi/collection/myoclonus_see_movement_disord ers-myoclonus

Information about reproducing this article in parts (figures,tables) or in its entirety can be found online at:

http://www.neurology.org/about/about_the_journal\#permissions

Information about ordering reprints can be found online:

http://n.neurology.org/subscribers/advertise

Neurology ${ }^{\circledR}$ is the official journal of the American Academy of Neurology. Published continuously since 1951, it is now a weekly with 48 issues per year. Copyright @ 2014 American Academy of Neurology. All rights reserved. Print ISSN: 0028-3878. Online ISSN: 1526-632X.

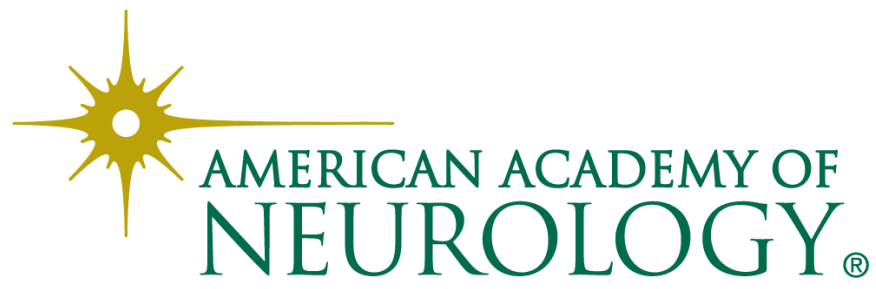

